\title{
A Scrutiny on the Cognisance of Indian and Foreign Wine Tourists on the Furtherance of Oenology Tourism in Bangalore
}

\author{
AvinThaliath ${ }^{*}$ and Tejinder Singh $\mathrm{D}^{\dagger}$
}

\begin{abstract}
Tourism is lively and dynamic. A continual search seems to happen over the new frontiers in technologies, and fresh destinations. This paper attempts to investigate Bangalore as a prospective destination for wine tourism, alongside benchmarking its evolution and management. Bangalore, given its resource rich status, is profoundly suitable to grow vines, most of which produce wine that meets international expectations and standards. The global benchmarking standards for wine tourism include dimensions such as infrastructure facilities for wine tourists, packages for the promotion of wine tourism, development plan related to wine tourism and goals for wine tourism Scale Testing of significant difference independent sample test and ANOVA - constructs by demographics. The findings say that the perception of both Indian and foreign respondents regarding the rating of each dimension of the promotion of wine tourism does not differ from each other.
\end{abstract}

Keywords: Oenology Tourism, Wine Tourists

\section{Introduction}

Wine is turning into a traveler product and choice. Rearing grapes vine was known to be an occupation by antiquated Egyptians 3500

\footnotetext{
* Co-Founder \& Director of Academics, Lavonne Academy of Baking Science and Pastry Arts, Bangalore, India; thaliathavin@gmail.com

† Research Scholar, Department of Hotel Management, CHRIST (Deemed to be University, Bangalore, India; tejinder0310@gmail.com
} 
BC. The vine and grapes were found in graves all through Egypt. Given the old records, it was realized that Assyrians made wine and wine culture had been known in Mesopotamia. Wine tourism is currently present in the most popular wine developing locales all through Europe, for example, Italy, France, Germany, Austria, and Spain. Besides, the United States of America, Australia, and New Zealand are very prominent from the viewpoint of wine developing area, wine tourism, viticulture, wine creation with farming, and effect on the economy of nature in which it shows. The visitors have a wide cluster of inspirations that incorporates exercises in a roundabout way identified with the wineand viticulture, for example, gathering quality wines, finding out about the outline and engineering of the basements where the wine is gathered and put away, and the way of generation, cooperation in the reap and support of the Vineyards.

Customarily, viticulture tourism was centered on voyagers propelled principally by enthusiasm for wineand with a powerful urge to visit the spots identified with tasting and purchasing wine. Viticulture tourism was at first defined by Hall (2000), and Hall \& Macionis (1998) as "appearance to vineyards, wineries, wine celebrations, and wine appears...." This definition stresses on wine and wine-related exercises as the primary thought processes for a traveler who is going by wine areas. This suggests wine tourism ought to incorporate more than a basic visit to wineries or vineyards. A winestreet is an area that offers a rare type of wine, provides food to travelers, and rural results of the wine area. It comprises of common magnificence, the specifics of nature through which the street leads, social and chronicled legacy, custom, and uniqueness of vineyard regions. Wine growing zone incorporates various wine makers, and in addition, those included in viticulture, wine generation, and different claims to fame of the district. The grape region is a current and possibly viniculture zone where wine street passes. The grape region incorporates vacation destinations and resorts that are nearer to the wine course of the street, on the off chance that it expands the offer of ethno-tourism. Making a wine street incorporates a scope of exercises, for example, meaning of providing food benefits on the wine course, characterizing the course of winestreet, altering space for getting visitors, yard, setting up street signs, advancement, and development of the vacation 
erofferetcetera.The primary standard for characterizing the wine street is the offer of wine and other neighbourhood delights in the vineyard families.

\section{Review of Literature}

Tourism, as an industry, is lively and dynamic. The continual search seems to happen over the new frontiers in technologies, nascent markets and fresh destinations. A rampant increase in tourist traversing the globe could be attributed to attractive packages that range from cruises to adventure and medical to spiritual-you name it, they have it. The visitors set in motion a change in the local communes, culminating in immense social and economic impact. However, the foremost challenge here is to reconcile growth with sound practices of development. Tourism as an industry is quite zippy, which is why customer satisfaction and security have remained the cornerstone of the tourism business (Dymond,1997).

Macionis (1998) proposed the model wine tourism consideringa unique interest in wine propelled by the goal (wine district), movement (wine sampling), or both. In any case, littleresearch has been done on the theme of wine tourism; however, it stands to profit the back-ward country territories. (Hall \& Macionis \& Johnson, 1998). Past reviews on wine tourism havebeen more cantered around the supply side, leaving a huge hole in the investigation of traits of wine vacationers, their acquiring behavioral and attitudinal attributes (Hall and Mitchell, 2000). Wine tourism has step by step raised tourism among the nations of the world. (Halletal, 2000 \& Rautetal, 2012) With respect to the travelling experience, and it also produces additional motivation for making the trip. (Macionis and Camborne, 1998) The place and sort of visitor are vital to decidingthe free market activity of wine tourism. This tourist falls under the classification of Special Interest Tourism (SIT). Such tourisms become relevant when travelers would want to go beyond the sun and sand to embrace an entirely unique set of activities specifically connected to a destination. (Hall, 1996).

Tourist needs variety and is fed up of regular destinations.Tofuel the motivation of a traveler' sinterest in tourism, wine tourism plays 
a significant role in attracting and drawing tourists to peripheral destinations. (Macionis \& Cambourne, 1998). Wine tourism is brought up emerging out of learning of characteristics that potential wine sightseers might want their "traveler item"to incorporate, frequently adjusted to their wishes and desires. (Dowling, 1999). Generally, the tourists around the world are largely motivated by leisure, clubbed with cultural and heritage visits, gastronomical delights and country side travels.However, there is a challenge in analyzing and building theory around tourist motivations as they are heterogeneous groups. Their tastes, preferences, desires, and expectations differ based on the destination, budgets, and experience, which the travelers themselves are not much aware of (George, 2005). In this way, the idea of wine tourism is scattered between wineries, wine districts, and guest buyers.

All things considered, Charters and Aliknight (2002) observed that wine tourism is not about drinking wine, but rather a thorough thought of going by wineries, tasting wine, going to the region, appreciating the view and furthermore going to nearby attractions. Wineries at once play the role of producer and place for consumption. (Leiper \& Carlsen, 1998) attracting winery visitors to gather, taste, and purchase. Consuming wine moderately is not only a pleasurable experience, but also carries itself substantial health benefits for consumers (Dodd 1997).Wine tourism is hard to ignore as it provides interesting activities for a visitor, ranging from witnessing grapes harvested, grape stomping, wine taster to know the tricks of wine production, bottling and blending and most fun of all is to stay right in the middle of expansive vineyards.

Wine tourism rotates around the wine locale, wine item, and winery with cordiality structure and guests. Modern wineries offer facilities which include local food, accommodation, conveyance etcetera. The connection between wine product and hospitality environment can facilitate the togetherness of wine tourism (Dodd, 1995; Bruner 2004). Motivation to meet the wine maker adds value to the winery experience (Cambourne \& Macionis,2000). As far as local communes are concerned, wine is integral to food festivals. And it helps promote the wellbeing of domestic dwellers. In numerous advantages have been credited to the improvement and 
effective usage of wine tourism. Benefits gather, for example, business development, creating work; offer of items locally, attracting guests to rustic territories; open doors for the venture, and that's just the beginning.

\section{Objective}

Wine Tourism has emerged as a potentially important factor in the field of hospitality and tourism in their respective functions and performance. The objective of this paper is to understand the perception of both Indian and foreign wine tourists on the promotion of wine tourism in Bangalore. The paper focuses on the four determinants and their perception over the Indian and foreign tourists.

\section{Research methodology}

Data Screening-collected data was screened before starting the analysis, especially checking the outlier, data entry error, handling missing values, all these are taken care of to ensure that, data analysis is started on the cleaned data.Cronbach alpha is done for all the constructs for checking the reliability to assess the consistency and quality of the data which are measured in rating scale testing of significant difference - independent sample t-test and ANOVA - constructs bydemographics.

\subsection{Instrument}

The global benchmarking standards for wine tourism include dimensions such as infrastructure facilities for winetourists, packages for the promotion of wine tourism, development plan related to wine tourism, and goals for wine tourism. All of the above-mentioned standards for benchmarking wine tourism in Bangalore has been used against the benchmarking criteria of the world.

\subsection{Construction of Questionnaire}

Based on suggestions from peers, two sets of questionnaires were designed. The first was pertaining to tourists visiting wine tourism in Bangalore. A structured questionnaire was designed with 
relevant items (questions) and was addressed to 150 tourists whom 100 respondents were Indians, and the remaining 50 were foreigntourists.

\subsection{Scoring}

The questionnaire pertaining to wine tourists consisted of 45 questions. Most of the questions were Likert based questions with a scale from 1 to 5 . No reverse scoring item is given in the questionnaire. The responses were based on the importance factor ranging from "Very Important, the scoring was 1", Important, scoring of 2", Can't Say, scoring of 3", Least Important, scoring of 4 " and "Not at all important, scoring of 5".

\subsection{Data Collection}

The researcher in person had gathered information from an aggregate of 150 respondents from wine tourists who visited Bangalore during wine tourism held in 2014. Similarly, a personal visit was made to each wine promoter. The poll was eventually regulated to every one of them. Obvious directions were given to fill the reactions to the things in the instrument. Respondents were guaranteed that the data that they share will be utilized for scholarly research and will be kept secret. After the accumulation of polls, information was entered and efficiently utilized for further examination.

\section{Analysis}

\subsection{Reliability and Validity}

We had made five dimensions, namelyinfrastructurefacilitiesfor wine tourists, packagesforthepromotionof wine tourism, development plan related to wine tourism, and goals for wine tourism. The reliability test for each of the above dimensions was carried out. Reliability implies repeatability of measure. It additionally mirrors the consistency of the reactions. The interim of unwavering quality test that has been utilized as a part of the review is Cronbach's alpha. It is a measurement thatmeasures the interior consistency of the instrument. Alpha coefficients go between 0 to1. The higher the estimation of alpha (ideally more than 0.70 ), the more solid the scale is. An alpha score of at least 0.70 
can be acknowledged as a decent dependability coefficient. The Cronbach alpha for each category is provided in table1.

Table 1: Cronbach Alpha results by component-wise of promotion of wine tourism

\begin{tabular}{lcc}
\hline \multicolumn{1}{c}{ Factor/component } & $\begin{array}{c}\text { Cronbach } \\
\text { Alpha }\end{array}$ & $\begin{array}{c}\text { No. of } \\
\text { items }\end{array}$ \\
\hline $\begin{array}{l}\text { Infrastructure facilities for wine tourists } \\
\text { Packages for the promotion of wine }\end{array}$ & 0.707 & 12 \\
tourism & 0.725 & 4 \\
$\begin{array}{l}\text { Development plan related to wine } \\
\text { tourism }\end{array}$ & 0.783 & 6 \\
$\begin{array}{l}\text { Goals for wine tourism. } \\
\text { Overall }\end{array}$ & 0.687 & 7 \\
\hline
\end{tabular}

So, we can see that in all the above cases, Cronbach's alpha score is either more than or equal to the acceptable limit of 0.70 excepted for one factor having only two items. This indicates good internal consistency of the items in the scale. The questionnaire has been given a final shape based on the suggestions and feedback of respondents and people from the industry who were able to give a better idea about the requirements which the industry looks for employees' work environment in general. This helped to ensure the validity of the instrument.

Table 2: Demographics

\begin{tabular}{llll}
\hline Age & $<25$ yrs & 20 & $13.30 \%$ \\
& $<30$ yrs & 48 & $32.00 \%$ \\
& $<40$ yrs & 52 & $34.70 \%$ \\
& $<50$ yrs & 18 & $12.00 \%$ \\
Gender & $>50$ yrs & 12 & $8.00 \%$ \\
Nationality & Male & 94 & $62.70 \%$ \\
Learn about wine tours & Female & 56 & $37.30 \%$ \\
& Indian & 100 & $66.70 \%$ \\
& Foreigners & 50 & $33.30 \%$ \\
& Newspaper & 12 & $8.00 \%$ \\
Occupation & Flyer/coupon & 6 & $4.00 \%$ \\
& Internet & 104 & $69.30 \%$ \\
& Friends & 28 & $18.70 \%$ \\
& Professional & 38 & $25.30 \%$
\end{tabular}




$\begin{array}{lll}\text { Academic } & 46 & 30.70 \% \\ \text { Agriculture } & 26 & 17.30 \% \\ \text { Student } & 0 & 0.00 \% \\ \text { Government } & 40 & 26.70 \%\end{array}$

On the analysis of the above table, the respondents $<40 \mathrm{yrs}$ achieved the highest score of $34.7 \%$ while respondents $>50 \mathrm{yrs}$ achieved the lowest score of $8 \%$.(Graph1) Male respondents achieved the highest score of $62.7 \%$, while female respondents achieved the lowest score of $37.3 \%$. The respondents with Indian nationality achieved the highest score of $66.7 \%$,while foreigners achieved ascore of $33.3 \%$. The internet was the topmost source to learn about wine tours (at $69.3 \%$ ), while flyers and coupon achieved the lowest score (at $4 \%$ ) to learn about wine tours.Occupation Academica chieved thehighestscorewith $30.70 \%$. This was followed by government with $26.7 \%$ while agriculture achieved the lowest score with $17.3 \%$.(Table1)

\subsection{Independent Sample T-Test}

\begin{tabular}{|c|c|c|c|c|}
\hline & Indian & Foreigners & t value & $P$ value \\
\hline Facilities Available & 3.39 & 2.34 & 10.5 & 0 \\
\hline $\begin{array}{l}\text { Factors promoting wine } \\
\text { tourism Importance }\end{array}$ & 4 & 3.28 & 6.57 & 0 \\
\hline Development Plan Available & 3.49 & 3 & 5.99 & 0 \\
\hline Goals for wine tourism & 3.32 & 3.71 & -2.76 & 0.00 \\
\hline $\begin{array}{l}\text { Success factors for wine } \\
\text { tourism }\end{array}$ & 3.78 & 3.89 & -1.11 & 0.26 \\
\hline
\end{tabular}

5

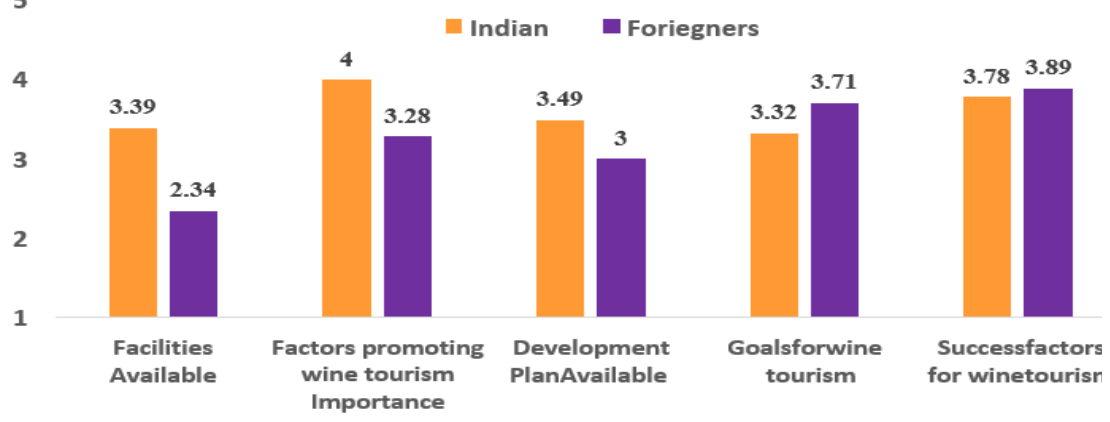


On the analysis of the above table, facilities available: Indians achieved the $\mathrm{M}=3.39$ while foreigners achieved the lowest $\mathrm{M}=2.34$, $\mathrm{T}=10.5$ and $\mathrm{P}<.05$, the mean difference existing about the perception of this factor is significant at $5 \%$ level.Factors promoting wine tourism importance: Indians achieved the $\mathrm{M}=4$ while foreigners achieved the lowest $\mathrm{M}=3.28$., $\mathrm{T}=6.57$, and $\mathrm{P}<.05$. Development plan available: Indians achieved the $M=3.49$ while foreigners achieved the lowest $\mathrm{M}=3$., $\mathrm{T}=5.99$, and $\mathrm{P}<.05$. Goals for wine tourism: Indians achieved $\mathrm{M}=3.32$ while foreigners achieved the lowest $\mathrm{M}=3.71$., $\mathrm{T}=-2.76$, and $\mathrm{P}<.05$. Success factors for wine tourism: Indians achieved $\mathrm{M}=3.78$ while foreigners achieved the lowest $\mathrm{M}=3.89$., $\mathrm{T}=-1.11$, and $\mathrm{P}=26$. Since the significance value is more than 0.05 , the mean difference existing about the perception of this factor is not significant at $5 \%$ level. Hence null hypothesis is accepted.

\subsection{Inferential Analysis: Independent T-Test:}

$\mathbf{H}_{0}$ : There is no significant difference in mean scores of four dimensions of namely infrastructure facilities for wine tourists, packages for the promotion of wine tourism, development plan related to wine tourism, and goals for wine tourism between Indian and foreign tourists.

Table 4: Results of T-Test of Each Dimension of Promotion of Wine Tourism Across Type of Tourists

\begin{tabular}{|c|c|c|c|c|c|}
\hline Variable & $\begin{array}{l}\text { Type of } \\
\text { tourist }\end{array}$ & Mean & SD & $\begin{array}{c}\mathrm{t}- \\
\text { value }\end{array}$ & p-value \\
\hline \multirow[t]{2}{*}{ Infrastructure facilities } & Indian & 17.120 & 2.804 & & \\
\hline & Foreign & 20.160 & .800 & -5.214 & $0.000^{*}$ \\
\hline \multirow{6}{*}{$\begin{array}{l}\text { Packages for the } \\
\text { promotion } \\
\text { Development plan } \\
\text { related to wine tourism } \\
\text { Goals for wine tourism }\end{array}$} & Indian & 4.960 & .935 & & \\
\hline & Foreign & 7.160 & 1.281 & -6.939 & $0.000^{*}$ \\
\hline & Indian & 27.960 & 1.369 & & \\
\hline & Foreign & 26.000 & 0.085 & 7.160 & $0.000^{*}$ \\
\hline & Indian & 29.360 & 1.846 & & \\
\hline & Foreign & 28.160 & 1.993 & 2.209 & $0.032^{*}$ \\
\hline
\end{tabular}

* Significant at $5 \%$ level.

It is observed from Table 4 that is a significant difference (as pvalue is greater than the significance level alpha of 0.05 ) in mean 
scores between Indian and foreign tourists with respect to all dimensions of promotion of wine tourism. Hence, the null hypothes is isrejected, and an alternative hypothesis is accepted. In other words, the perception of both Indian and foreign respondents regarding the rating of each dimension of the promotion of wine tourism does not differ. Accordingly, as the mean score of foreign tourists $($ mean $=20.160)$ is marginally higher than Indian tourists (mean=17.160), one would conclude that foreign tourists are giving overall little higher rating importance on infrastructure as compared to their Indian counterpart regarding the promotion of winetourism.

\section{Conclusion}

Tourism in India has been moving upwards, especially after the campaign of "Incredible India." In the year 2014, Indian tourism sector generated close to about 95\$ Billion.This represented 6.6 percent of GDP for the country that year. This sector is estimated to grow at an average annual rate of 7.9 percent till 2023, which makes India the third fastest-growing destination over the next decade. Approximately 40 million jobs are created by the tourism sector alone annually. Wine tourism in India and particularly in Karnataka, has been flourishing during the last decade. Conducive climatic conditions, appropriate soil conditions, responsive government policies and schemes, farmers' support, and flow of investments can be cited as good reasons for wine tourism to thrive in Karnataka. Our study was to focus and sharpen our understanding of those significant points that contribute to the promotion and welfare of wine tourism in India and particularly in Karnataka. For our study, we have chosen those research questions that seem to answer generic concerns on the wine industry and specifically wine tourism. In the demographics, we can find more respondents fell within middle age, i.e., between 30 - 40 years. Less than 20 years and more than 50 years seemingly have lesser inclination to travel, and even if they do travel, there is little chance they would move out of conventional tourist cliques to explorative ones. Middle age theory works fine since these days, families are small, and most of them are double-income families. It translates to more of disposal incomes for purposes beyond mere survival. No 
motive or intention can be cited for the same. Wine tourism world wide is attracting foreign tourists more than the local populace. Thus, we have also included responses from foreign tourists who seem to be almost half of the native respondents. Moreover, when it comes to the question as to how people negotiate the various media to get information about wine tourism. Most of them rely on internet sources, followed by word of mouth references. We are living in the age of digital information. Every piece of information that we seek to have is literally at a click of the button. The searches have been far easier and more particular and accurate with the advent of Internet technologies. This could also be the reason why online communities and reviews are becoming too influential in drawing customers to buy products and services over the internet.

\section{References}

Alonso, A. D. (2009). Travelers Interested in Wine Tourism in New Zealand? International Journal of Culture, Tourism and Hospitality Research, 3(1), 13-24.

Bruwer, J. \&. (2009). The Hedonic view of WineTourism Consumption: an Experiential View.International Journal of Wine Business Research, 21(3), 235-257.

Cambourne, B. (1998). CreatingTourism Vintages: A Practitioners Guide to Wine Tourism. Proceedingsof the First Australian Wine Tourism Conference, Margaret River Western Australia 9th May. Bureau of Tourism Research, Canberra.

Carlsen, J. (2004). A review of global wine tourism research. Journal of Wine Research, 1(15).

Dodd, T. (1997). Techniquesto Increase Impulse Wine Purchases in a Restaurant Setting. Journalof Restaurant and Foodservice Marketing, 2(1), 63-73.

Dymond, S. J. (1997). Indicators of sustainable tourism in New Zealand: A local government perspective. Journal of Sustainable Tourism, 279-293.

George, B. P. (2005). Measuringtourist attachment to holidays: Some preliminary results. Tourism An International Interdisciplinary Journal, 52(3), 229-246.

Getz, D. D. (1999). Critical Success Factors for Wine Tourism. International Journal of Wine Marketing, 20-43.

Hall, C. (1996). Winetourism in New Zealand. In G. Kearsley (ed.) Tourism Down Under II, Towards a More Sustainable Tourism ConferenceProceedings. Centre for Tourism, University of Otago, (pp. 109-119). 
Hall, C. a. (2000). Wine tourism in the Mediterranean: a tool for restructuring and development. Thunderbird International Business Review, 445-65.

Hall, C. C. (1998). Wine Tourism andNetwork Development in Australia and New Zealand. International Journal of WineMarketing, 3.

Hall, C. C. (1998). Wine Tourism andNetwork Development in Australia and New Zealand: Review, Establishment andProspects. International Journal of Wine Marketing.

Hall, C. C. (1998). Wine Tourism aroundThe World. ButterworthHeinemann, UK.

Leiper\& Carlsen Go, F. W. (1997). Applyingimportance-performance analysis to Beijing as an international meetingdestination. Journal of Travel Research, 35(4), 42-49.

Mitchell, R. a. (2006). Wine tourism research: the state of play. Tourism Review International, 9(4), 307-32.

Raut, A. \&. (2012). Wine tourism in Maharashtra: Problems and Solutions. Asian Journal of Food andAgro Industry, 5(2), 141-155.

Williams, P. (2001). Positioning Wine Tourism Destinations:An Image Analysis. International Journal ofWine Marketing, 42-58. 